\title{
TECHNOLOGY TRANSFER IN INDONESIAN STATE UNIVERSITIES: DO IPRS PLAY A SIGNIFICANT ROLE?
}

\author{
Puspa Kriselina Asmoro*
}

* Kyushu University, Japan

\section{Article Info}

Received : 15 March 2016 | Received in revised form : 19 July 2016 | Accepted : 23 March 2017

Corresponding author's e-mail : puspakriselina@yahoo.com

\begin{abstract}
The activity of knowledge and technology transfer from the academic side into businesses or the industrial sectorthrough various schemes, so-called university technology transfer or academic technology transfer, involvesa complex process of developing research ideas into the utilization of research. Historically, university technology transfer was triggered by amendment of the U.S. Patent Law, named the Bayh-Dole Act. Shortly after the amendment, technology transfer activity atU.S. universities escalated, particularly in patent and license activities. The movement of transfer technology was closed related toa research activity of the university and university patent in general. Through empirical study, this paper identifies technology transfer activities specifically on herbal pharmaceutical products at two Indonesian state universities,i.e.InstitutPert anian Bogor and Universitas Indonesia. The identification of technology transfer activity in both universities aims to study whether IPRs play a significant role in technology transfer activity.
\end{abstract}

Keywords: university technology transfer, technology transfer, research commercialization, patent commercialization, utilization of research

\begin{abstract}
Aktivitas transfer teknologi dan pengetahuan dari sektor akademik ke sektor bisnis atau industry dapat dilakukan melalui berbagai skema, antara lain transfer teknologi perguruan tinggi atau transfer teknologi akademik, yang melibatkan proses pengembangan ide penelitian menjadi pemanfaatan riset. Berdasarkan sejarah, transfer teknologi universitas dipicu oleh amademen UU Paten Amerika Serikat, yaitu Bayh-Dole Act. Tidak lama setelah amandemen, aktivitas transfer teknologi di perguruan tinggiAmerika Serikat meningkat, khususnya dalam kegiatan paten dan lisensi. Pergerakan transfer teknologi berkaitan erat dengan aktivitas riset dari universitas dan paten universitas secara umum. Melalui penelitian empiris, tulisan ini mengidentifikasikan aktivitas transfer teknologi khususnya dalam produk farmasi herbal di dua universitas negeri Indonesia, yaitu Institut Pertanian Bogor dan Universitas Indonesia. Identifikasi dari kegiatan transfer teknologi di kedua universitas bertujuan untuk mengetahui apakah hak kekayaan intelektual memiliki peranan penting dalam aktivitas transfer teknologi.
\end{abstract}

Kata kunci: transfer teknologi perguruan tinggi, transfer teknologi, komersialisasi riset, komersialisasi paten, pemanfaatan riset 


\section{INTRODUCTION}

Start-up businesses, as one of technology transfer schemes, have been growing significantly at a place named Silicon Valley. The famed place in northern California, with hundreds of technology start-up companies, has become a model of how innovation was created and how technology transfer occurred. The accomplishments of the Silicon Valley are inseparable from the contribution of academic circles, for instance Stanford University. Since the beginning, Stanford University was actively involved in the development of northern California's Silicon Valley. Over the last 30 years, Stanford University has played an active role as forerunner in university technology transfer and biotechnology industry. ${ }^{1}$ At the present time, Stanford University's role in university technology transfer has turned into a model for R\&D institutions as well as education institutions worldwide. ${ }^{2}$ However, creating innovative technology and transferring such technology from the laboratory level to the end product for public benefit, is not simple and in fact it is rather difficult. ${ }^{3}$

Technology transfer is a wide-ranging issue which occurs in many fields, for instance, in business to business, industry to industry, and academic to industry or business, etc. This paper will focus on transfer of technology in the academic field. So called "university technology transfer" describes the activity of transferring knowledge and technology from academic circles to businesses or the industrial sector through various schemes. What is technology transfer? It is "defined as a process for conceiving of a new application for an existing technology. It is also defined as a process for converting research into economic development. The term technology transfer is also used to mean licensing intellectual property to a manufacturer for production, or reducing an idea to practice in a prototype, or even the process of recording concepts of technology know-how in a professional paper or patent application."4

Technology transfer is, in reality, a structural process of learning. The key components of a transfer can be identified as knowledge derived from real-world experience together with human expertise capable of transforming that knowledge into action. (Hari Srinivas)

University technology transfer was triggered by the Amendment of United States Patent Act in 1980 known as "Bayh Dole Act"5 (hereinafter 'the Act'). The main purpose of the Act was to enhance technology transfer activity in the academic area, particularly for technology developed by government funding. The main issue of the Act was that it altered the ownership right of technology, from the government side to the university concerned. The transfer of ownership provided the university with the flexibility of utilizing research or technology and the possibility to obtain economic

\footnotetext{
1 Lawrence Fisher, “The Innovation Incubator: Technology Transfer at Stanford University," http:// www.strategy-business.com/article/13494?gko=e8e48, accessed March 30, 2015

${ }^{2}$ Ibid.

3 Jennifer Henderson and John Smith, "Academia, Industry, and the Bayh-Dole Act: An Implied Duty to Commercialize," https://www.cimit.org/news/regulatory/coi_part3.pdf, accessed October 16, 2014.

${ }^{4}$ Hari Srinivas, "Technology Transfer for Sustainable Development," available at http://www.gdrc.org/ techtran/techtran-sustdev.html, accessed November 20, 2014). Detail information about author: Dr. Hari Srinivas is a Coordinator of Global Development Research Center which has a main office in Kobe, Japan. He is also a Professor of Environmental Policy and Sustainability, Graduate School of Policy Studies, Kwansei Gakuin University, Japan.

5 The Act was initiated by Senators Birch Bayh and Robert Dole, it moved through Congress in 1980 and became law in December, 1980, with an effective date of July 1, 1981. See Jennifer Henderson and John Smith, "Academia, Industry, and the Bayh-Dole Act: An Implied Duty to Commercialize," available at https://www.cimit.org/news/regulatory/coi part3.pdf, accessed October 16, 2014. See also Joseph P. Allen, "A Quick History of Bayh Dole", available at http://www.bayhdolecentral.com/legislative_history.php accessed July 9, 2015).
} 
benefit from the technology utilized. The Act led to a massive progress in university technology transfer in the Unites States (hereinafter referred to as 'the U.S.'). Shortly after the enactment of the Act, an escalation of patent and license activities occurred at U.S. universities. ${ }^{6}$ The Act also brought an impact on other countries. Several countries adopted similar provisions as those set out in the Act in their national legislation.

Even though the Act has brought significant impact on university technology transfer in the U.S. and influenced several other countries to adopt similar provisions, the academic debate as to whether the rules under the Act fundamentally influence university technology transfer is still ongoing. Supporters of the Act argue that the existence of the Bayh Dole Act has indeed provided an incentive for university technology transfer. It provides, they argue, wider access to technology utilization as well as public access to technology itself. Prior to the enactment of the Act, the public had less access to technology. Despite the fact that at that time the technology belonged to the government, the public did not receive any benefit from it. The technology developed through public investment (tax money) never brought benefit to the public. However, after the enactment of the Act, universities and the industry engaged in further collaboration and transformed the basic technology developed within universities into accessible products. By doing so, it brought greater benefit to the public. In contrast to the above, opponents of the Act argue that the existence of the Act has not been the singular factor which has influenced university technology transfer. Other factors may have been involved in technology transfer activity. Additionally, they point to empirical evidence indicating that even prior of the Act, university technology transfer had been functioning properly at some universities in the U.S. Accordingly, the existence of the Act offers insufficient proof that the Act has brought a profound impact. ${ }^{7}$

Transfer of technology ownership is not the only issue in the area of university technology transfer, as broadly discussed in academic papers. Technology transfer involves several stages, starting from technology development, technology utilization and beneficial return. Each stage involves several activities. In the technology development stage, the activity starts with finding financial support for the research, conducting the research, discovering a new technology, protecting an intellectual property and assessing the technology. In the technology utilization stage, the activity continues with prototyping, finding counterpart, manufacturing, marketing and so on. The final stage, the beneficial return stage, involves an activity of distributing the financial benefit.

In the technology development stage, a majority of research developed at universities is basic or fundamental research. Generally, basic or fundamental research produces a low level of technology. It means that the technology cannot be directly applied to the end product. The technology needs to be polished in the advanced research stage in which the university concerned sometimes needs support from a counterpart. Generally, the office for university technology transfer takes charge of connecting university technology with other parties. The office facilitates the university in finding a partner for utilization purposes. Technology may be transferred from the university side to the other party through several schemes - for instance, licensing, start-up business, selling, self-manufacture, spin-off company and so on.

${ }^{6}$ See Valerie Landrio McDevitt, Joelle Mendez-Hinds, David Winwood, Vinit Nijhawan, Todd Sherer, John F. Ritter and Paul R. Sanberg, "More Than Money: The Exponential Impact of Academic Technology Transfer," Technology And Innovation 16 (2014), pp. 75-84.

7 Henderson and Smith, "Academia Industry," See further David Mowery, Richard Nelson, Bhaven Sampat,and Arvids Ziedonis, "The Growth of Patenting and Licensing by U.S. Universities: An Assessment of the Effects of the Bayh-Dole Act of 1980," Research Policy 30 (2001), p. 100. 
The complex issue of technology transfer has brought multi-discipline scholars into discussion on various issues. Apart from ownership issues and the influence of the Bayh Dole Act, most scholars also raise a discussion on several issues related to the scheme of university and industry relation and venture capital.

In Indonesia, state universities have created qualified seed researches. Most of the researchers receive support funds from the government for research; however, unfortunately, most researches end up with a report paper, article in journals or piles of paper. Only a few of the technology developed or the product of research are either transferred or applied to end products.

Technology transfer activity at Indonesian state university does not appear to be very effective, with the limited number of records on collaboration between university and industry. In addition to that, technology and product have been receiving little attention from the industry side. Intellectual Property Rights, especially patents, which are expected to be able to provide incentive for university technology transfer or commercialization, do not appear to be bringing significant influence on the said activity. Such ineffectiveness may be caused by several problems.

To understand the current situation of technology transfer activity at Indonesian state universities, this paper presents an identification of university technology transfer specifically in the area of herbal pharmaceuticals. Through such identification, this paper will further study whether IPR protection in technology plays a significant role and provides incentive in promoting technology transfer activity.

\section{HISTORICAL BACKGROUND OF UNIVERSITY TECHNOLOGY TRANSFER}

Historically, the movement of technology transfer in the educational zone was triggered by the U.S. In the U.S., university technology transfer growth was identified as an influence of the amendment of the patent law, named the "Bayh Dole Act". Prior to the enactment of the Act ${ }^{8}$, conditions of research utilization or university technology transfer had been more or less comparable with the situation faced by most universities worldwide. At that time, government funded research at U.S. universities hardly produced viable products or services, and as a result, technology licensing was occurring only at a low level of technology. Moreover, ownership rights of technology developed at university belonged to government, with an argument that research developed with support from public funding or tax money should be returned to the public, placed under government title. ${ }^{9}$ As an effect of this though, almost 30,000 patents were placed under government title; unfortunately only a small percentage of such patents were able to be utilized through the licensing scheme with the industry. ${ }^{10}$ In addition, at that time,

U.S. was experiencing double-digit inflation and double-digit unemployment; U.S. was predicted would lose its lead in high technology to Japan and Germany; U.S.

8 Bayh-Dole Act refers to the amendment of U.S. Patent Law. United States of America, 35 U.S. Code Chapter 18 § 200-212 - Patent Rights in Inventions Made with Federal Assistance.

9 Henderson and Smith, "Academia Industry", See also Robert C. Miller, Bernard J. Le Boeuf, and associates eds. Developing University - Industry Relations - Pathway to Innovation from the West Coast (San Francisco, CA: Jossey-Bass, 2009.) Miller and Le Boeuf mentioned that "federal government was owner of intellectual property rights of research funded by government".

${ }^{10} \mathrm{Ibid}$. It was recorded that only $5 \%$ of patent could commercialize at that time. See also Association of University Technology Managers, "The Bayh Dole Act: It's Working," available at http://www.autm.net/ AM/Template.cfm? Section=Bayh Dole Act\&Template=/CM/ContentDisplay.cfm\&ContentID=11603, Valerie Landrio McDevitt, Joelle Mendez-Hinds, David Winwood, Vinit Nijhawan, Todd Sherer, John F. Ritter and Paul R. Sanberg, "More Than Money: The Exponential Impact of Academic Technology Transfer, "Technology And Innovation, Vol.16 (2014) 75-84, 76. 
universities performed R\&D, but few inventions were commercialized; the federal government held title to about 28,000 patents, of which fewer than $5 \%$ were licensed to industry for development of commercial products meaning that American taxpayers were not getting full benefit from billions of dollar invested in cutting-edge research. ${ }^{11}$

Facing the said obstacles, the U.S. government made an effort to reform government policy in regards to innovation matters. In response to those issues, in 1980, the U.S. government adopted the "Bayh-Dole Act". The Act represented essential changes in innovation policy in the U.S. government. ${ }^{12}$ "It's fundamentally altered the ownership paradigm of intellectual property developed with federal research fund, transferring that ownership from federal government to grant recipient (grantees) and organizations that are parties to government funding agreement (contractors), in an effort to enhance the public's access to technology developed with federal funds." ${ }^{13}$ Provision of the Act employed to all research schemes which carry out under government funding agreement, included to all research wholly or partially funded by the government. ${ }^{14}$ Naturally, the Act implied tasks for university and industry to work together and to create partnership, at the same time it changed university and industry relationship from traditional into assigned partnership, with the aim to advance technology and giving more benefit to the public. ${ }^{15}$

The feature combination of Bayh-Dole, 1) stated goal of increased public access to federally-funded research; 2) provision for the transfer of intellectual property to grantees/contractors, and 3) identification of the crucial role of industry in transforming ideas into available products and services, create an implied duty on the part of grant recipients and government contractors to partner with industry to commercialize promising federally-funded research.

(Henderson and Smith, 2002:1)

Changes in innovation and intellectual property policy significantly altered the condition of technology utilization or commercialization at U.S. universities enabling them to utilize research more than before the adoption of the Act. Additionally, the existence of the Act brought significant impact on education institutions in conducting their forthcoming research utilization.

A study has recorded that in the U.S. shortly after enactment of the Act, universities' productivity in patents increased by about sixteen times, the establishment of technology transfer office increased by 100 (hundred) times, and it recorded that such patents were further utilized through the licensing scheme and brought turnover into

11 Association of University Technology Managers, "The Bayh Dole Act: It's Working," available at http://www.autm.net/AM/Template.cfm?Section=Bayh Dole Act\&Template=/CM/ContentDisplay. cfm\&ContentID=11603, accessed October 16, 2014.

12 Ibid.

${ }^{13}$ Henderson and Smith, "Academia Industry.".

14 Einar Rasmussen, Øystein Moen, Magnus Gulbrandsen, "Initiatives to Promote Commercialization of University Knowledge," Technovation 26 (2006), p. 520. See further Jennifer Henderson and John Smith, "Academia, Industry, and the Bayh-Dole Act: An Implied Duty to Commercialize," available at https://www. cimit.org/news/regulatory/coi part3.pdf, accessed October 16, 2014. According to Henderson and Smith "The Bayh-Dole University and Small Business Patent Procedures Act of 1980 (the Bayh-Dole Act) fundamentally altered the ownership paradigm of intellectual property developed with federal research dollars, transferring that ownership from the federal government to grant recipients (grantees) and organizations that are parties to government funding agreements (contractors), in an effort to enhance the public's access to technology developed with federal funds."

15 Henderson and Smith, "Academia Industry.". 
universities. ${ }^{16}$ This notable record of patenting and licensing achieved by universities in the U.S. is believed to have been a direct impact of the existence the Act. ${ }^{17}$

Based on the new system and policy, universities in the U.S. could conduct utilization of research specifically research funded by the government. Universities were also allowed to receive benefit from patents or innovation commercialization. The Act provides a formal permission to utilize research in concrete schemes and as an incentive for universities, and it offers an opportunity to obtain economic benefit from it. ${ }^{18}$

Existing data indicate that the U.S. foreign exchange earnings primarily originate from royalty as the result of patent commercialization. It has been recorded that " $75 \%$ (seventy-five percent) of foreign exchange comes from royalty and the remaining $25 \%$ (twenty five percent) comes from export of tangible products." ${ }^{19}$ Such current condition in the U.S. was acknowledged as a result of successful change of the patent policy in last 1980, called the "Bayh-Dole Act".

The has Act received pros and cons among scholars. With the substantial achievement of the Act, scholars argue that the development of technology transfer in the U.S. has been a direct effect of the Act. The Act "gave university ownership of inventions developed through the use of federal funds and created strong incentives for technology transfer." ${ }^{20}$ The advocates of Bayh-Dole also argue that "the findings of publicly financed university research require considerable additional R\&D and other investments before they can be commercialized; such investments are more likely if a firm is granted an exclusive license to do that work. But if the findings of publicly funded university research are placed in the public domain or are inexpensively licensed to anyone who wants to use them, competition alone may stimulate their widespread application." ${ }^{21}$ However, according to Henderson and Smith, provisions of the Act were not at all new; rather, it included similar provisions as proposed in previous recommendations. Yet, the study showed that patent activity increased commercialization activity in the U.S., "certainly they increase commercialization deals between universities and companies, though it is hard to know the extent to which that simply reflects the fact that once a patent issue, the company in question needs a license in order to commercialize the technology."22

On the opponent side of this Act, Mowery, Nelson, Sampat, and Ziedonis "suggest that Bayh-Dole was based on concerns that were misstated or at least overstated". ${ }^{23}$ According to their argument, in the development of technology transfer in the U.S. except the Act, there have been many elements involved and influenced. The rise of patenting and licensing activity has not been merely the result of the influence of the

${ }^{16}$ Mark A. Lemley, "Are Universities Patent Troll?," Fordham Intellectual Property, Media And Entertainment Law Journal 18 (2008).

17 David Mowery, Richard Nelson, Bhaven Sampat,and Arvids Ziedonis, "The Growth of Patenting and Licensing by U.S. Universities: An Assessment of the Effects of the Bayh-Dole Act of 1980," Research Policy 30 (2001), p. 100.

${ }^{18}$ Henderson and Smith, "Academia Industry", See also Rasmussen, Moen, and Gulbradsen, "Initiatives to Promote Commercialization"; Einar et al. stated that the Bayh-Dole Act provide "a formal responsibility for university for turning fundamental research into practical use when possible and at the same time an opportunity for getting extra-income."

19 Ahdiar Romadoni, Patent Valuation Strategy (September 27-28, 2013) (Unpublished presentation, Institut Teknologi Bandung) (on file with the author).

${ }^{20}$ Robert C. Miller and Bernard J. Le Boeuf, “Context and Constraints," in Developing University-Industry Relations - Pathways to Innovation from the West Coast, eds., Robert C. Miller, Bernard J. Le Boeuf, and associates, (San Francisco, 1st Edition CA: Josey-Bass, 2009).

${ }^{21}$ Mowery, Nelson, Sampat,and Ziedonis, "The Growth of Patenting".

${ }^{22}$ Lemley, "Are Universities Patent Troll?".

${ }^{23}$ Ibid. 
existing Act; based on their research, the act only affected limited units in university research, culture and norm. ${ }^{24}$ They argue that technology transfer activity in the U.S. had existed and had been functioning properly at some universities even before the Act came into existence. In addition to the above, intellectual property protection did not have much influence on technology transfer activity, as with or without it, the activity of technology transfer still occurred. ${ }^{25}$ They also state that the Act provides a 'blanket permission"26 which allows universities to file patent under their title and further commercialize it through partnership with other parties. ${ }^{27}$ In support of their argument, Mowery et al. also conducted an analysis concerning the effect of the Act on several universities which had already been quite active in patenting and technology licensing prior of the Act as compared to those that started to be active after the enactment of the Act. Based on their observation and empirical evidence, prior to the enactment of the Act, universities in the U.S. had already been actively conducting patenting and licensing activities. An example of such active technology licensing was Stanford University and the University of California. On the other hand, they used Columbia University as an example of university which became active in licensing technology after the enactment of the Act. With regards to Columbia University, with the adoption of the Act they were compelled to start patenting and licensing activities, hence the Act brought strong influence on technology transfer activity at Columbia University. ${ }^{28}$ However, Mowery, Nelson, Sampat and Ziedonis, stated that the issue raised was complex and needed further research in order to analyze it.

Besides supporters and opponents of the Act, there are scholars who still question the influence of the Act in university technology transfer activity. Einar Rasmussen, øystein Moen, Magnus Gulbrandsen, raised the question as to "whether patents and exclusive licensure [are] the best way to maximize social returns of public R\&D investment?" ${ }^{29}$ I also raise similar questions. Moreover, in my view, patents are not the only IPRs which are related to this issue; rather, other IPRs may also be involved.

The flourishing of university transfer technology in the U.S. has encouraged countries to follow including Asian countries. The impact of the Act was influenced some countries and scholars to carry out a study on the subject and to formulate a similar regulation in other countries, including "China, Germany, Japan, Malaysia, Philippines, Singapore, South Korea." 30 In Asia, waves of university technology transfer have also influenced several countries to seriously carry out university technology transfer activity. Some Asian countries have also been influenced by the Act's provisions and have started to employ similar provisions.

\footnotetext{
${ }^{24}$ Mowery, Nelson, Sampat,and Ziedonis, "The Growth of Patenting".

${ }^{25}$ See Lemley, "Are Universities Patent Troll?", Lemley suggestion, See Mowery, et. al. Ivory Tower And Industrial Innovation: University Industry Technology Transfer Before And After The Bayh-Dole Act (Stanford, CA: Stanford University Press, 2004), p. 99-148.

26 Blanket permission or blanket authorization is formal, written consent given to an individual or entity to conduct an activity without requiring additional approval. Blanket authorization usually requires a form signed by a consenting party designating the authorized individuals and activities. Business Dictionary, "Blanket Authorization," http://www.businessdictionary.com/definition/blanket-authorization.html, accessed April 23, 2015.

${ }^{27}$ Mowery, Nelson, Sampat,and Ziedonis, "The Growth of Patenting".

${ }^{28}$ Ibid.

${ }^{29}$ Rasmussen, Moen, and Gulbrandsen, "Promote Commercialization".

${ }^{30}$ Association of University Technology Managers, "The Bayh Dole Act," available at http://www.autm. net/Bayh Dole Act1.htm, accessed December 27, 2014.
} 


\section{III.UNIVERSITY TECHNOLOGY TRANSFER IN JAPAN AND SOUTH KOREA: A BRIEF OVERVIEW}

\section{A. Japan Policies in Research and Technology Transfer}

In Japan, universities are divided into three types, i.e. private universities, public universities and national universities. ${ }^{31}$ Amongst the said three types of universities, "national universities are receiving the largest amount of research funds from the industrial sector (these funds account for $70 \%$ of the funds given to national universities), [even though] the great majority of Japanese universities are private universities." ${ }^{2}$ Such support from the private sector to national universities indicates that national universities are considered as important players in university and industry partnership in Japan. ${ }^{33}$

In terms of technology transfer law and regulation, " Japan's current science and technology agenda is based on two pieces of legislation: (1) the Science and Technology Basic Law of 1995 and (2) the Science and Technology Basic Plan of 1996 (revised in 2001)."34 "The Basic Plan for Science and Technology stresses the importance of promoting collaboration between university and business." ${ }^{35}$ This Basic Plan sets "five-year strategy for improving the national infrastructure supporting public R\&D and better linking scientific research to societal needs." ${ }^{6}$ "The First Basic Plan promoted a system for joint industry-university-public R\&D. Under this plan, the government broadly increases its budget for science and technology. With industry-university-public alliances and cooperation as the central pillar, the plan also indicated measures for promoting more exchanges between industry and academia, and enhancing the applicability of research results. ${ }^{\text {“37 }}$ The second phase plan in 2001-2005, "industry-university-public alliances are currently being advanced in the following ways: promotion of organic alliances between government, industry and academia, and the construction of a technology innovation system that would continually produce innovative services and resources; use of industryuniversity-public alliances to facilitate the transfer of technology from universities and public research institutes to the industrial sector; and planning of environmental improvements needed to invigorate venture businesses." ${ }^{38}$

Partnership between university and industry in R\&D has taken certain forms in Japan, whereby in common form "they consist of cooperative research, which means either joint research, where company and the university work together through a signed contract, or commissioned research, where the company commissions the university to do specific research for them." ${ }^{39}$ It could also in general "include the licensing of patents, i.e. the transfer of university developed intellectual property, the

31 Koji Nishio, "Development Of University-Industry Partnerships For The Promotion Of Innovation And Transfer Of Technology: Japan," available at Http://Citeseerx.Ist.Psu.Edu/Viewdoc/Download;Jsess ionid=7ea49a844863ff02ced17afb2c7ee78b?Doi=10.1.1.129.1837\&Rep=Rep1\&Type=Pdf, accessed January $1,2015$.

32 Ibid.

33 Ibid.

34 Ibid.

35 Risaburo Nezu, et. al., "Technology Transfer, Intellectual Property And Effective University-Industry Partnership The Experience Of China, India, Japan, Philippines, The Republic Of Korea, Singapore And Thailand," Geneva, WIPO, 2007.

${ }^{36}$ Steven Collins and Hikoji Wakoh, "Universities and Technology Transfer in Japan: Recent Reforms in Historical Perspective," Journal Of Technology Transfer 25 (2000), p.. 219.

37 Nishio, "Development Of University", See Also Collins And Wakoh, "Universities And Technology Transfer," p. 219.

38 Ibid.

39 Ibid 
launching and supporting of ventures spawned from university research products, and personnel exchange between company and university, i.e. the dual employment of faculty members at a company or vice versa." ${ }^{40}$

The Japanese government has made endeavors towards supporting the university and industry relation through several additional government policies, which could "be divided into four measures as follows: (1) the promotion of technology transfers from universities to companies and the strengthening of intellectual property management within the university; (2) the encouragement of cooperative research between university and company and the effective utilization of the national R\&D programs; (3) the promotion of personnel exchanges between company and university, and (4) the launching of university born venture businesses." ${ }^{11}$

To promote university technology transfer as mentioned in point 1 (one), the University Technology Transfer Promotion Law of 1997 was issued. "This law enabled the formation of Technology Licensing Organizations (TLOs), intermediary organizations that could facilitate the transfer of university research products to the private sector. After beginning a nationwide initiative to investigate the possibilities for strengthening and protecting intellectual property in 2000, the government, in 2002, formulated the Intellectual Property Basic Law, which laid out the basic outlines for intellectual property strategy. Concrete measures for the promotion of intellectual property in universities were laid out in the Intellectual Property Promotion Plan, put together in 2004." 42

To promote university and industry cooperative research, the government releases "the limitations on corporate funds going into national universities, and meanwhile passed the Special Measures for the Revitalization of Industry Law in 1999, which made it possible for the conductors of nationally commissioned R\&D to own resulting intellectual property rights." ${ }^{43}$ "The Industrial Revitalizing Law of 1999 (which established a legal structure similar to that created in the Bayh-Dole Act in the U.S.)" 44 further enacted in support of the transfer of technology.

The most important law, law to alter the legal status of national universities from a government institution to an independent administrative entity was took effect in April 2004. The purpose of this law goes well beyond facilitating U-I collaboration. It aims to render the Japanese national universities more responsive to the changing needs of society by giving them more freedom of conduct on the one hand, but at the same time, making them more accountable for creating value in Japanese society. University was given independent legal status; this new arrangement enables them to own the technologies and inventions that they develop. Researchers and faculty members in the national universities are no longer bound by the regulations applicable to government employee. This law altered the attitude and mindsets of the university researchers with respect to collaboration with the private sector. ${ }^{45}$

To promote exchange of personnel between university and industry, "The Industrial Technology Reinforcement Law of 2000 recognized the public benefit of allowing national university faculty members, who were technically national public servants, to hold dual employment in companies who were in receipt of their research products. At the same time, reforms in the National Personnel Authority regulations have been made to encourage the contribution of national university faculty members
${ }^{40}$ Ibid.
${ }^{41}$ Ibid.
${ }^{42}$ Ibid.
${ }^{43}$ Ibid.
${ }^{44}$ Nezu, et, al, "University-Industry Partnership".
45 Ibid. 
to industrial activities." ${ }^{46}$

Lastly, to support business venture, "the government has not only loosened the regulations concerning faculty contributions to companies, but it has also implemented such government measures as the 1000 University-Based Venture in 3-Years Plan." ${ }^{47}$ Whereas business venture is one of the indicators for determining how effective technology transfer is through the existence of University-Spawned ventures (spin-off) in Japan. It was recorded that in March 2005, more than 1000 university spin-off were created in Japan. ${ }^{48}$ Currently, Japan's strategy is to focus on bringing such university spin-off to the stage of Initial Public Offering (IPOs). ${ }^{49}$

However, with the development of technology transfer in Japan, it has been recorded that there has been "negative indicator that reveal weakness in Japan, whereas Japanese company spare more that 2 (two) times as much money on collaboration with foreign university than Japanese university, especially in hightechnology such as IT and Biotechnology (the gap widens to 10 times) with reason that Japanese university are less responsive to the needs of business, slow to act and less experienced in managing IPRs." ${ }^{10}$

\section{B. The Rapid Growth of University Technology Transfer in South Korea}

South Korea has developed several regulations to facilitate the technology transfer activity. Such regulations, "the laws related to co-operation and technology transfer are specified as the Invention Promotion Law, a law for building up the base of Industry \& energy technology, industry development law, special law for raising venture enterprise, technology transfer promotion law, science technology basic law, patent law, law for industrial education promotion \& co-operation boost and so on." ${ }^{1}$ In particular, there are "4 laws specifying utilizing co-operation and research results of universities among them, such as the science technology basic law, technology transfer promotion law, the patent law, and a law for industrial education promotion \& co-operation boost." 22

One of the regulations, the Science and Technology Basic Law, sets out the fundamental ideas that "to make research \& development and utilization of science technology have harmony with natural environment and social ethics based on human dignity, make scientific technicians' autonomy and creativity to be respected, and make Natural Science and [Human] Social Science development mutually balanced." ${ }^{33}$ In addition, this law is "aiming at planning national economic development, further contributing to improvement of people's lives, quality, and development of human society, by building up the basis for science technology development, innovating science technology and strengthening national competitiveness," ${ }^{54}$ which also lines out the policy that the "Korean government should set up mid and long term policy

${ }^{46}$ Ibid. See also Collins and Wakoh, "Universities and Technology Transfer," pp. 213-222.

${ }^{47}$ Nishio, "Development Of University".

${ }^{48}$ Nezu, Kiang, Ganguli, Nithad, Nishio, Tansinsin, Yi, and Yujian, "University-Industry Partnership".

${ }^{49}$ Ibid.

50 Ibid.

${ }^{51}$ Hwa-Cho Yi, "Korean Experience In Fostering University-Industry Partnerships," available at http:// www.wipo.int/export/sites/www/uipc/en/partnership/pdf/ui_partnership_kr.pdf, accessed January 1, 2015.

${ }^{52} \mathrm{Yi}$, "Korean Experience", See further Kim, seung kyun, development strategy of university technology transfer organizations, intellectual property rights research center of Korea intellectual property office, December 2003.

${ }^{53}$ Ibid.

${ }^{54}$ Ibid. 
goals and direction for science and technology development in order to achieve the objectives of law most efficiently; should include measures for spreading technology transfer and promoting the utilization of research; regularly collect indexes and statistics, predict trends and evaluate the effectiveness of its policy (reliable statistics are the basic for an objective assessment of a policy effectiveness)." ${ }^{55}$ Based on the Basic Law, the "Minister of Science and Technology is required to make an executive plan every year, Chief of Central Administrative Organization and the Chief of Local Bodies are to make and implement the yearly plan in accordance with the Basic Law." 56

Moreover, the Korea Government has set up a "Technology Transfer Promotion Law (2000); prior to such law, national and public universities did not have the status of a legal person and therefore could not claim patent rights. The rationale behind this rule was that the result of publicly funded research should belong to the public domain, not to the organization that developed them." ${ }^{57}$ However, "Article 16 of the Technology Transfer Promotion Law reversed this statute in order to enable publicly funded university to work with businesses and use their technology and knowledge for commercial purposes. Under the new arrangement, researchers in national universities have been allowed to not only work with a private sector, but also take a slice of the earning in the event that the project generated revenue." 58 The changing of paradigm into knowledge-based-society poses a new challenge to universities in Korea, whereby "universities are facing academic capitalism, meaning that universities should play a new role as a core subject for creation, conveyance, and spread of knowledge, not as the existing role for conveyance of knowledge." ${ }^{59}$

In conducting R\&D within the university, Korea's supplies of funding for research come from government, public organizations, private companies and private corporations. Research funded by public organizations is commonly research based on "academic curiosity and spirit of inquiry over research proposal," 60 while on the other hand, research funded by private companies "have an objective-oriented characteristic accepting their demands by consultation with supporting organizations. Co-operatives between enterprises and universities are providing a chance to strengthen company innovation, particularly with small to mid-sized companies." ${ }^{11}$

To facilitate the technology transfer activity, the Korean government has established Industry University Cooperation Foundation (IUCF) which is responsible for the management of IPRs at each university. ${ }^{62}$ It was recorded that technology transfer conducted in Korea totaled 58 in 2001, 102 in 2002, and 133 in 2003 (which involved 19 Korean private universities in 2003$)^{63}$ respectively. Through technology transfer, universities received 0.473 billion won (2001) and 1.913 billion won (in 2003) as an income and at the same time patent applications increased dramatically. ${ }^{64}$ In addition, facilitation of technology transfer also occurred through the Science Park. The Science Park is described as an area where researchers are able to completely interact with industrial and trading groups with the purpose of developing commercialization of

\footnotetext{
${ }^{55}$ Nezu, Kiang, Ganguli, Nithad, Nishio, Tansinsin, Yi, and Yujian, "University-Industry Partnership".

56 Ibid.

57 Ibid. See further Hwa-Cho Yi, "Korean Experience In Fostering University-Industry Partnerships," available at http://www.wipo.int/export/sites/www/uipc/en/partnership/pdf/ui partnership kr.pdf

58 Ibid. See further Hwa-Cho Yi, "Korean Experience In Fostering University-Industry Partnerships," available at http://www.wipo.int/export/sites/www/uipc/en/partnership/pdf/ui partnership kr.pdf

${ }^{59} \mathrm{Yi}$, "Korean Experience",

${ }^{60}$ Ibid.

${ }^{61}$ Ibid.

62 Nezu, et. al., "University-Industry Partnership."

${ }^{63}$ Ibid.

${ }^{64}$ Ibid.
} 
high tech technology. ${ }^{65}$

\section{TECHNOLOGY TRANSFER ROADMAP}

Technology transfer activities involve a complex process from developed research idea to research utilization, as can be seen in the figure below.

\section{Figure 1. University Technology Transfer Road Map}

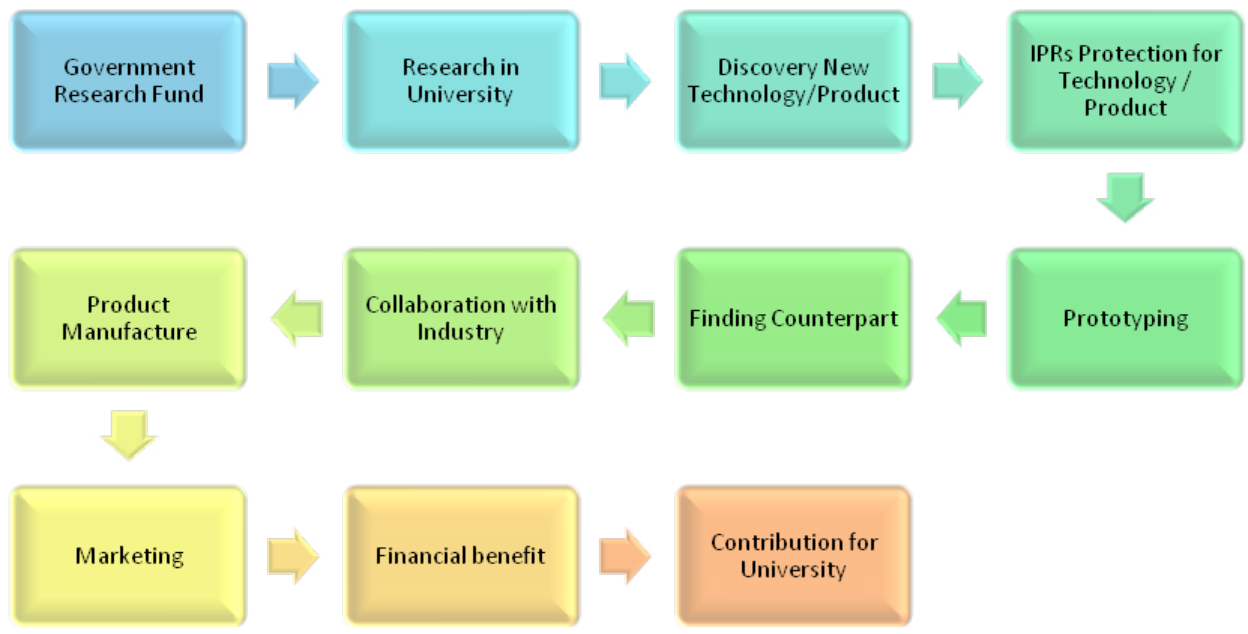

This roadmap is used by academic institutions with a modification made to adjust to each situation. Technology transfer involves several activities starting from research idea, finding research fund, carrying out research up to discovering new technology, intellectual property protection, prototyping, finding counterpart to enter into the utilization phase, collaboration with counterparts, manufacturing product or technology, marketing product, financial benefit sharing, and sharing contribution for parties involved. Due to the long and complex process of technology transfer, in this paper I would like to simplify this process from idea into the research utilization into 3 (three) main categories; (1) technology development phase, (2) technology utilization phase and (3) beneficial return phase (please refer to figure 2 below).

The first phase starts with the research idea, getting financial support to execute the research idea, conducting research at university resulting in new technology or product, and processing intellectual property protection for the result of research. ${ }^{66}$ Financial support, in the first phase, mostly comes from government funds. However, there is a possibility that university may receive research funds from another party.

65 Amir F. Manurung, Komersialisasi Teknologi [Technology Commercialization] (Jakarta: Kementerian Riset dan Teknologi, 2012), p. 20. See further on Byungho Oh presentation on seminar of "Korea: 38 Years Technology Commercialization Management in Science Park" presented on November 29, 2011.

${ }^{66}$ Elements which create technology in the technology development phase are respectively closely related with the input for preparing sufficient supply of technology which "requires appropriate combination and quantities of the input. The inputs embrace the various factors of production such as raw materials, machinery, factories, land, labor and management. Some of these inputs are combined into packages that economist call a "plant" and that the census of manufactures calls an establishment." See Lester Telser, Willian Best, John W. Egan, Higinbotham N. Harlow, "The Theory of Supply with Applications to The Ethical Pharmaceutical Industry," Journal of Law And Economics 19 (1975), pp. 449 -478. 
Research process within the university involves several elements, including human resources (researchers and team), facilities (laboratory, machinery, equipment, factory, etc.), materials, and so on. Once the research is done, the issue as to whether or not the technology needs to obtain intellectual property protection will arise, as well as the issue of who will become the owner of the technology concerned.

Research developed at university is typically basic or fundamental research, with a low level of technology readiness for end product application. Technology developed at university, in the beginning stage, is difficult to apply to a marketable product. It will require another stage to advance the technology and to apply it to a marketable product. To enter the second phase, the technology utilization phase, the university has to complete the technology development phase. The accomplishment of the technology development phase can be measured based on the availability and quality of technology that resulted from research activity in the technology development phase.

The second phase, the technology utilization, starts with the assessment process, prototyping, product manufacture, up to marketing of the product. In this second phase, the university through the Technology Transfer Office will promote to transfer the available technology or product to the other party (industry or company) through various schemes including but not limited to licensing and selling technology. In some cases, technology transfer occurs through the establishment of a Start-Up Company or Spin-Off Company. In the event of transferring a low readiness level technology through any of the above described schemes, it will require further investment by the university's counterpart in regard to advancing the technology to the marketable product. Additional investment by counterpart may be in the form of advance development of the research, prototyping, manufacturing stage and marketing the product at the end. The third phase, the beneficial return phase, is basically a benefit that can be potentially received by accomplishing the two previous phases.

Figure 2. 3 Phases of University Technology Transfer Road Map

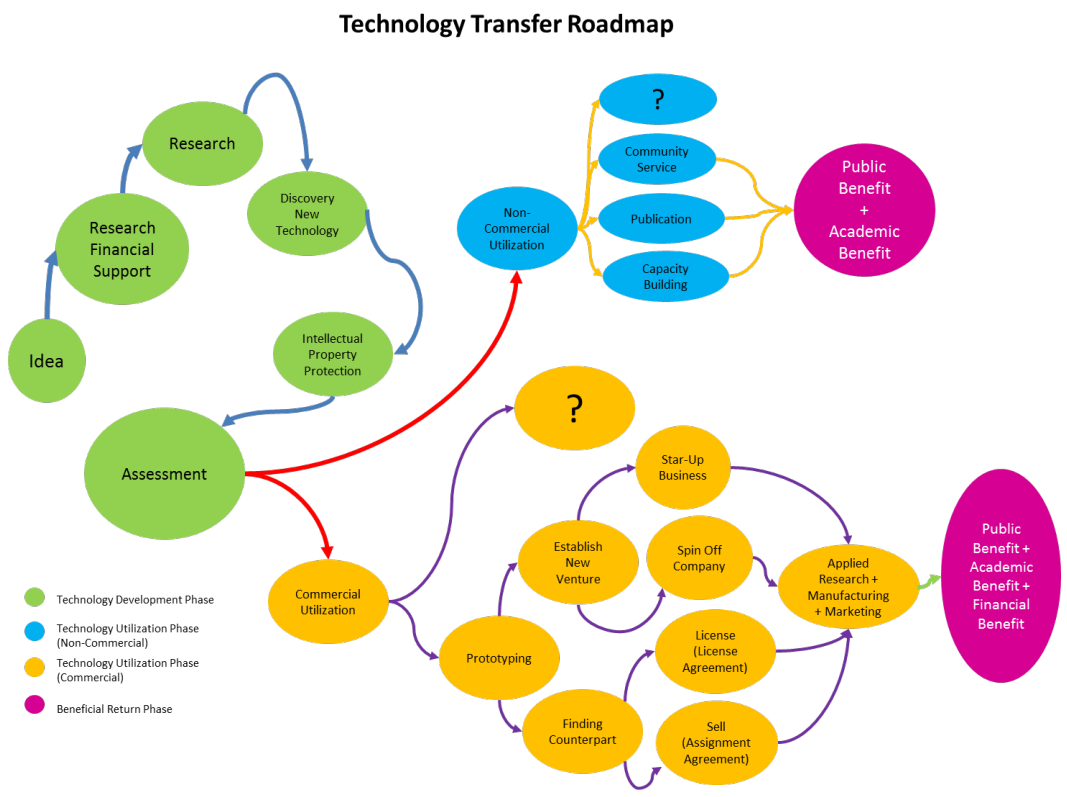




\section{PATENT AND COMMERCIALIZATION}

University technology transfer was closed related to patented activities of university as can be seen at Stanford University and other universities' experience around the globe. The technology developed through research within the university is further protected under patent rights. Scholars have argued that the patent is closely related with university technology transfer from the beginning of an idea into utilization, nevertheless, in my view, other Intellectual Property Rights (IPRs) may also be involved to facilitate the technology transfer activity. There is always a possibility that the result of research can also be protected under other IP regimes, for instance trade secret, trademark, industrial design, and so on. In some instances, IPRs may not be needed at all in technology utilization.

To some extent, IPRs are important to universities for academic record purposes, as an achievement of the university, as well as an achievement of its researchers. Patents in particular can provide financial return to the university concerned in the future through utilization of technology under a commercial scheme.

"The classic justification for patents is creating incentives to innovate". ${ }^{67}$ In addition to the above, it provides future financial benefit if the technology is utilized. However, patent is not the only incentive in research and/or technology transfer. "There are plenty of incentives for university scientists to engage in research, including curiosity, academic prestige, tenure and promotion. Compare to other incentives, rational reason is that patent may generate some revenue, which is refunded to the researcher, researcher's department, university and could financially supports further research. But the contribution of patents to university incentives to innovate seems smaller than in profit-driven companies." 68

Another issue is the commercialization argument, namely why the utilization of technology needs a profitable framework. "Unlike the classic incentive story, commercialization theory argues that it is not so much the act of invention, but instead the act of turning that invention into a marketable product that requires investment and therefore the exclusion of competition." ${ }^{69}$ According to the commercialization theory, "university inventions will waste away and not be commercialized unless we give someone (initially the university, but presumably eventually a private company to which the right is licensed or transferred) control over the invention, and therefore incentive to invest in developing and marketing it."? By logically assuming that invention at university mainly involves basic research and it is created at an earlier stage, such argument seems to be a reasonable one. After all, basic research and low readiness level of technology require an advanced step in order to become a marketable product.

\section{IDENTIFICATION OF TECHNOLOGY TRANSFER ACTIVITY IN INDONESIAN STATE UNIVERSITIES}

\section{A. Methodology}

This research has been carried out through empirical study. It has identified technology transfer activities, specifically on herbal pharmaceutical products at Indonesian state universities, i.e. Institut Pertanian Bogor (hereinafter referred to as IPB) and Universitas Indonesia (hereinafter referred to as UI). The empirical study was conducted through in-depth interviews in May 2015. It involved several

\footnotetext{
${ }^{67}$ Lemley, "Are Universities Patent Troll?".

${ }^{68}$ Ibid.

${ }^{69}$ Ibid.
} 
actors within the universities closely involved in university technology transfer activities, including but not limited to the universities' Intellectual Property Office, the universities' Research Institute, researchers, the universities' holding company, marketing unit and so on, with a total of 13 respondents from both universities.

The choice of herbal pharmaceutical field for the empirical study has been made based on the reason that according to my observation, herbal pharmaceutical area is currently quite productive in terms of innovative products at universities. The product of research on herbal pharmaceutical field could be classified as the closest to the end and marketable product, therefore, its preparation to enter the market is much easier compared to other technologies or products in other fields. Additionally, "most universities and research institutions in Indonesia have conducted researches which include: research on traditional medicines of certain tribes, including original formulation, usage, preparation, activities; research on the standardization of plant materials, determination of chemical constituents, bioactivity tests, toxicity tests, preclinical and clinical tests." Moreover, in the industrial sector, the herbal pharmaceutical industry in Indonesia has shown a rather significant growth as evident from the increasing number of companies and small and medium Enterprises in this field over the last five years. From the government side, the herbal pharmaceutical industry has also received special attention and assistance from the governmentEmpirical Evidence of Technology Transfer Activity at Indonesian State Universities

In reviewing university technology transfer at Indonesian state universities and in determining whether IPRs play a significant role in technology transfer activity, identification of university technology transfer in the herbal pharmaceutical field was carried out through empirical study as a model in this discussion. Through such empirical study, some data and information were gathered concerning the current situation at both universities (IPB and UI) in conducting technology transfer.

At IPB and UI, research related to herbal pharmaceutical products was carried out by researchers who are mostly lecturer at the said universities. Research, up until resulting in herbal pharmaceutical product, was conducted by researchers with the support of government funds or other sponsors under various research grant schemes.

As a brief overview, through the in-depth interviews the same situation in relation to several technology transfer elements was found at both universities. Similar conditions were found with respect to the issue of research financial support, technology readiness level, researcher mindset, industry relationship, incentives for researchers, market demand on herbal product, university's internal policy on IP protection and technology transfer, university productivity in patents and government support for technology transfer at the university concerned.

Additionally, through the interviews I also found different conditions at each of the said universities in regard to certain elements. Such difference was found with regards to the issue of university perspective of technology transfer, parties within the university involved in technology transfer and their respective roles, technology transfer schemes, strategy of product manufacturing, marketing strategy and benefit of technology transfer. Some of the elements will be described briefly below.

\section{Research Financial Support}

Both universities received financial support mostly from the government through the scheme of $A P B N, D I P A, B O P T N$. In addition to the above, UI also received financial support from a private sector party through the CSR program and partnership, grant from a specific institution and Non Governmental Organization (NGO), and from 
national or international institutions through the partnership and collaboration scheme.

IPB received financial support from the government through the Ministry of High Education, the Ministry of Research and Technology and Ministry of Agriculture under the grant scheme National Innovation System Research Incentive (Insentif Riset Sistem Inovasi Nasional - SINAS), Excellent Integrated Research (Riset Unggulan Terpadu - Menristek), the IPB Excellent Research Program, Higher Education grant, LPDP Grant.

Some specific grants are also available for technology transfer, namely IPTEKDA LIPI, LPDP, Ib-IKK (Ipteks bagi Inovasi dan Kreatifitas Kampus)[Science for Campus Innovation and Creativity), and PUSNAS DIKTI (Penelitian Unggulan Strategis Nasional)[National Strategic Research of Excellence]. Each of the grants has specific requirements.

\section{University Internal Policy in IPR Protection and Technology Transfer}

Both universities have internal policies that regulate IPR protection of technology resulting from research, as well as technology transfer activity. At IPB, there are 3 (three) internal regulations in regard to this issue, meanwhile UI has only 1 (one) internal regulation. The internal regulation deals with several issues, including technology ownership rights, IPR protection and internal royalty scheme in terms of technology utilization and so on.

In regard to IPR protection, both universities encourage all potential research output to obtain IPR protection. IPR protection facilitated by the university is in the form of copyrights, patents, and trademarks. Specifically in patent applications, the university facilitates registration, including patent drafting, financial support for registration, and financial support for patent maintenance fee.

At UI, under its internal regulation, IPR ownership of technology developed at the university with the support of government funding belongs to the university. The university will request an inventor to sign the transfer of right agreement, to transfer ownership right from the inventor to the university. There is also a possibility of joint ownership if the technology is developed through research in doctoral studies. Research funding may also be supported by a third party (for example a company as the student's employer or his/her home university). Joint ownership is also possible in the case of collaboration with another institution (for example, research center outside the university, industry, company, other educational institution). In the event that technology utilization or commercialization occurs, the internal regulation also sets out a royalty scheme. ${ }^{70}$

At IPB, IPR ownership of technology developed at the university is entirely, $100 \%$ owned by the government; however, similar to UI, ownership title is in the university's name. There is a possibility for another ownership scheme if another party is involved in research. As an example, a joint ownership may occur if there is collaboration with an industry which results in product or technology, or research of a postgraduate student who received financial support from their home institution, resulting in a technology. In terms of royalty scheme, at IPB $60 \%$ of the royalty will go to the university and its research center and $40 \%$ to the inventors. .

${ }^{70}$ The data and information are based on interviews conducted in May 2015 and UI Rector Decree No. 1571/SK/R/UI/2009 concerning IPRs Management of UI. 


\section{University Perspective on Technology Transfer}

UI's perspective on technology transfer is limited to commercialization of patent product. At UI, technology transfer also occurs through community service program. Under the community service program, UI utilizes research results for community purposes.

At IPB, the University tries to apply all technologies developed by themselves in the community and industry. IPB applies the same through commercial and noncommercial (community service) schemes.

\section{Technology Readiness Level}

At both universities, namely UI and IPB, innovation resulting from university research is not yet ready as a marketable product. Researches are only conducted at the laboratory level and research accuracy still questionable. Products or technologies require an advanced step in order to be able to become a marketable product.

However, certain products resulting from research, particularly in the area of herbal pharmacy, are capable of entering the market. Research results of the product are possible to be applied as an end product and marketable product. Particularly in the area of herbal pharmaceuticals, the research carried out in both universities resulted in several herbal products as an output of research.

At IPB, the Biopharmacha Research Center (BRC) is closely involved in herbal product development. Around 30 herbal products have been developed through the research center. Currently, although on a small and medium scale, such products are already being manufactured and have entered the market. At UI, Muhamad Sahlan is one of the researchers focusing on herbal product development, particularly in regard to propolis. Some of his products have also been manufactured on small and medium scale, and have entered the market.

\section{The IPR Protection and Its Benefits}

Both universities, namely UI and IPB, are encouraging their researchers to protect all research results under IPRs. UI and IPB's internal regulations in regard to intellectual property protection are facilitating such issue, particularly in patent and copyright protection. Both universities also facilitate financial support for IPR registration for their researchers. However, in practice, not all research results have been protected under IPRs. Only some of the researchers are aware of the importance of IP protection.

Although significant research has been produced by both universities, the IPR registration record has been rather limited. Patent applications at UI total about 15 applications yearly, 2 of which are for herbal products. At IPB, patent registrations total about 20-25 applications yearly, out of which about 2-5 applications are for herbal products.

In the technology development phase, to some extent, the purpose of obtaining IPR protection, patent in particular, was to obtain academic credit point for promotion. Some lectures or researchers have registered their research results for such particular purpose, although there were some other researchers who registered their research results for other purposes, for instance commercialization purpose. In addition, from the universities' perspective, having a significant amount of university patents could raise the university ranking and it can be considered as an academic achievement. Therefore, the universities encourage IPR protection for the research output. Up to 
this point, IPRs in the technology development phase have brought academic benefit to the researcher and the university.

In the product utilization or commercialization phase, based on IPB's experience, the holding company of IPB, namely BLST Co., which facilitates the technology transfer activity, does not require a patent or any other IP protection for product manufacturing or marketing. They will facilitate any marketable product, with or without IPRs. According to their view, if the product is already patented, it will be a value added to the product. However, even if it is not patented, it would be no problem for them to facilitate the utilization of product concerned as long as it is marketable. They understand that IPR protection creates an exclusive right, which could be an incentive, however, they also know that the procedure to obtain patent protection takes took a long process and requires extra energy and effort. If they have to wait until a patent is obtained, they may lose the business opportunity. Therefore, for them, obtaining a patent for the product is not a necessity for the utilization of technology.

In UI's experience, the university IP office tries to commercialize all patent products which belong to the university. Currently, the IP Office facilitates patent licensing for certain products (for instance, the propolis products). Patent licensing is not an easily implementable by UI, because the university has difficulty in identifying a counterpart as a licensee. Currently, the licensee is still limited to SMEs. Based on patent licensing, product have been manufactured and marketed on a small and medium scale. Financial benefit obtained as a result of licensing is not too significant.

\section{Technology Transfer Schemes Employed by UI and IPB}

Both universities employ several technology transfer schemes as described below:

a. Universitas Indonesia

\section{i. Personal contact between researcher/inventor with a partner from a company or industry leading to Licensing Scheme}

The researcher is the actor who knows well his/her products or technologies and knows well a company or industry that may be interested to work together with them. The partnership starts from an initiation by the researcher. The Researcher will coordinate with the University's IP Office concerning the draft of the License Agreement. At the same time, the researcher will contact and inform his/her faculty about the possibility of a partnership between him/her and the industry. On the part of the university, the finalization of the License Agreement will involve the researcher, the faculty, the University's IP Office and Directorate of Partnership. Under such scheme, in some cases, licensing of a product which has been granted a patent has occurred.

\section{ii. Voluntary System for Social Purposes}

The voluntary system was introduced by Prof. Raldi Artono Koestoer, an "antipatent" researcher from UI. Under this scheme, patent is considered to be unnecessary in the utilization of technology. According to him, patenting his technology or product would make it difficult to use it for humanitarian or social purposes. Without patent, his technology or product can be used for social purposes and it can potentially bring benefit for a long period of time.

In view of the social purpose of his innovation (an infant incubator), Prof. Raldi established a Non-Governmental Organization (NGO). Under this NGO, volunteers, who are spread in several areas and provinces in Indonesia, have the duty to deliver the infant incubator for every family who requests it. The infant incubator can be used for free based on the free lending system. After a family no longer needs it, they can 
return it to the volunteer. The volunteer can then further deliver it to the next family which needs it.

To support this program, several officers or volunteers have been trained by Prof. Raldi to manufacture the product (infant incubator). In addition, Prof. Raldi has also made a prediction of child birth rate in several areas in Indonesia. Based on such prediction, he will set up a volunteer team in a specific area that has a high rate of childbirth. Further, they will facilitate the availability of an infant incubator in those specific areas.

In January 2012, he started with the free lending system of the last version of the incubator. He set up a volunteer group in several cities in Indonesia, including Jakarta, Bandung, Subang and Tasikmalaya. In 2013, several areas were added, including Semarang, Magelang, Jogja, Solo, Malang, Jember, and Bali. The target in 2015 was 21 cities in Indonesia from Abepura to Banda Aceh. Up to the present time, Prof. Raldi and the volunteers are managing around 100 units of infant incubator based on the free lending system. Around 30 incubators have been available in the JABODETABEK area (around Jakarta City). Based on the records, in 2012, as many as 400 babies were saved by using a free lending infant incubator.

\section{iii. LPDP (Indonesian Endowment Fund for Education) Grant}

In supporting university technology transfer activity, the $1^{\text {st }}$ year program of LPDP Grant offers support in the manufacture stage of product or technology. The Grant may also include the establishment of a Start-Up Business. In the $2^{\text {nd }}$ year, the LPDP grant supports the marketable stage of product or technology. The LPDP Grant is based on an agreement between the university and LPDP as funder. The university has an obligation to ensure that the manufacture and marketing program will run as expected by the funder.

\section{iv. IPTEK DALIPI}

The IPTEK DALIPI program supports the establishment of SMEs which run based on a research activity. The recipient of the said grant receives funding to conduct product commercialization and has the obligation to provide a progress report to LIPI as funder.

The IPTEK DALIPI program is a funding program based on loan system. Since it is a loan system, the SMEs as recipients have the obligation to pay it back after a certain period of time and to provide a report to the funder. However, the loan payment money will not be taken by the funder; rather than that, it will be returned by the funder to the recipient, and it will be used to support further business activity.

\section{v. Research Collaboration}

Research collaboration has been conducted between university and a company or other universities. Most of research collaboration outputs were in the form of a collaborative article for a journal. Other research collaboration was in form of student exchange and technical test based on company or international company request.

\section{vi. Partnership}

A partnership scheme in this context means partnering between an inventor and a company where the inventor is part of the company as a partner or shareholder in the company concerned. The company is basically a company which is closely related to the inventor product or technology. Through such collaboration, the inventor endeavors to commercialize his/her product through the company.

Under this scheme, the inventor is closely involved in product development together with the company. The inventor is involved in the entire process from 
manufacturing up to the marketing stage, including deciding on packaging design and material, branding strategy, advertisement, marketing strategy, and so on. The company supports all necessary elements enabling the inventor to conduct product manufacturing. Through such collaboration, the inventor receives benefit in the form of company shares.

\section{b. Institut Pertanian Bogor}

\section{i. Academic Business Unit}

At IPB, technology transfer activities are mostly tackled by the academic business unit (sometimes referred to as commercial business unit). Around 30 academic business units have been legally established under an IPB Rector Decree. However, in reality, the number of existing business units is over more than 30 units. In addition to the 30 units which have a legal status, other units have been operated without having a legal status. Academic business units were first introduced since IPB obtained the status of a State University Legal Entity (PTN-BH). At that time, under its PTH-BH status, IPB was allowed to set up a commercial business unit. Fortunately, the current legal status also supports and facilitates the academic business units.

The academic business units manage faculty facilities, such as research equipment, laboratory, machinery and other facilities for business activities, in particular facilities that are not regularly used. In the course of business activities undertaken by academic business units, technology transfer occurred through several activities as follows:

(1) laboratory service;

(2) small scale product manufacture, particularly of products resulting from research activity by the faculty's department or research center;

(3) facilitating SMEs to manufacture the SMEs product using the unit's facilities.

Benefits from academic business unit activities, in form of financial benefits, are used for maintaining the facility and as an incentive to the human resources (including but not limited to researchers, staff, laboratory assistants, etc.).

Small scale product manufacture carried out by the business unit is part of the strategy of making all research results available as a product for public benefit, even without IPR protection. The manufacture stage is handled by the unit using university facilities within campus.

In the future, academic business units will have the opportunity to become a spinoff company. There is also a possibility that the units may become subsidiaries of the IPB Holding Company.

\section{ii. Research Collaboration}

IPB has also implemented a research collaboration scheme in technology transfer. Several collaborations were conducted between IPB researchers with an industry in regard to herbal pharmaceutical products as well as other products or technology. For instance, collaboration with PT. Indofarma concerning enzymes. Other research collaborations include collaboration with Ehime University and Bintang 7 Company regarding herbal products.

\section{iii. Commercialization Grant}

IPB has been providing commercialization grant for prospective research. Recipients of the Grant are selected based on screening by the Directorate of Research and Innovation. Recipients of the Grant have to collaborate with the IPB holding company in conducting commercialization, starting from the incubation 
stage. During the incubation stage, the holding company supports and facilitates raw material for manufacture, manufacture readiness program, marketing readiness program, transfer of ownership rights from individual researchers into the university and so on. The holding company also facilitates technology support together with the inventor; infrastructure support in the form of office facilities, fabric, and so on; and business support in form of marketing and distributing. Under the scheme of commercialization grant, the university will receive benefit in the form of dividends.

\section{iv. Personal Contact or Consultation}

In some cases, the industry prefers to contact an individual or a faculty directly rather than contacting the university as an institution. It is because the industry feels inconvenienced to have a connection with the university. From the industry's perspective, connection through the university will take longer to negotiate and a long administrative procedure. In addition to that, the industry needs to prepare advance funds for collaboration with the university. In contrast, direct contact with an individual researcher is much easier in terms of negotiation. Also, the industry does not need to pay everything in advance, since most of the companies or industries expect to see the results and output first before they pay. Such type of relation is mostly implemented within the framework of consultation in a specific field.

Although the industry contacts directly the individual researcher, the Memorandum of Understanding (MOU), Partnership Agreement and financial transaction should proceed through the university. In such framework, the university also encourages individual researchers or lecturers to involve students and the laboratory in the partnership scheme. Through such partnership, both students and the laboratory are also able to gain experience in research and the transfer of knowledge.

\section{v. Industrial Partnership Grant}

The industrial partnership grant is one of grants, which requires a partnership with an industry since the beginning. The industry involved as a partner in this scheme, should be able to provide a fund sharing. As an example, for a research or a product development with a yearly fund around IDR 400.000.000, industry should be able to cover around $25 \%$ of the total fund needed.

\section{vi. Spin-Off Company}

The Biopharmaca Research Center (BRC) is a center at IPB which focuses on research in herbal products. This research center has produced qualified researches in herbal products. It has an academic business unit which was formerly managed to transfer research results into herbal products through product manufacture inside the university. Through the said unit, research results were transformed into marketable herbal products. Technology transfer activity was conducted by self-manufacture of products. Furthermore, the unit also facilitated products in entering the market. In the course of time, the academic business unit was transformed into a Spin-Off Company under the name of PT. Biofarindo. Today, the company manages the manufacturing of products resulting from research conducted by the research center.

\section{Parties Involved in Technology Transfer Activity and Their Roles at Universities}

Technology transfer activity at UI involves researchers, Heads of Department, Research Managers of each faculty, the Dean of each faculty, Directorate of Innovation and Incubator Business (DIIB) and the Directorate of Research and Community Service (DRPM). At IPB, the parties involved are the Directorate of Business Development, Directorate of Research and Innovation, Research and Community Service Institute (LPPM), Research Center/ Department/ Faculty, Academic Business Unit, BLST Co. 
(IPB’s Holding Company) and Serambi Botani (BLST’s Marketing Unit).

The role of such parties at UI is as follows:

(a) The Head of Department facilitates administrative and management matters on behalf of the researcher.

(b) The Research Manager has the task to maintain and record a research database and manage research activity within the scope of the faculty.

(c) The role of the Dean is more of an administrative role.

(d) The Directorate of Innovation and Incubator Business has the task of implementing IPR protection and commercial utilization, managing the database of innovation at UI, identifying a counterpart for each technology developed, developing networking between university and the industry.

(e) The Directorate of Research and Community Service (Direktorat Riset dan Pengabdian Masyarakat/ DRPM) has the duty to manage the university research funds, as well as to handle research monitoring, reporting and evaluation. The unit also carries out non-commercial technology transfer through a community service program.

The role of the relevant parties at IPB is as follows:

(a) The Directorate of Business Development has the duty to manage university assets, particularly those related to land, research expertise, and network. They have to supervise academic business units that are managed under the department/ laboratory/faculty/research center.

(b) The Directorate Research and Innovation has the duty to manage all IPB technologies which are based on IPR protection. The Directorate has to facilitate all activities, starting from IPR Protection, promotion up to the commercial phase. The promotion strategy was implemented through advertising in 101-107 books, airlines magazines, advertorial in local media; active participation in expo; holding regular business meetings; facilitating a academic-business-governmentcommunity forum of; open innovation partnership platform; Door to Door meetings. The unit is also conducting talent scouting and supports small scale manufacture of products by the inventors.

(c) The Research and Community Service Institute (Lembaga Penelitian dan Pengabdian Masyarakat/LPPM) has the duty to facilitate research proposal to obtain financial support from a funder, providing information about research funding, At the same time, this institution also carries out screening of research grants, collects research reports and conducts monitoring and evaluation. The institute also carries out non-commercial technology transfer through a community service program.

(d) The Research Center's role is to conduct basic and advanced research. Furthermore, the unit also has the duty to prepare technology or product prototyping, in particular, technology or products that are ready to be applied to a marketable product. The unit also conducts several additional activities such as assisting local farmers, supplying raw materials and complementary materials to SMEs.

(e) Academic Business Unit is a unit that carries out small scale product manufacturing within the university, where the product resulted from university research. The technology or product developed within the university is transformed into marketable products through manufacturing by the unit. The unit also prepares prototype for each technology or product.

(f) Holding Company (BLST Co.).

The holding company facilitates business incubators, provides manufacture and 
marketing facilities. In addition to that, the holding company also supports IPB in identifying counterparts for university technology or products and facilitates business negotiations.

(g) The SERAMBI BOTANI (Marketing Unit)

The unit has the duty to conduct marketing, distribution and sales of university products. Its main role is supporting an entrepreneur program of IPB. The entrepreneur program (for instance, academic business unit) which is already running a product manufacture and marketing on a limited scale, will receive further marketing facilitation from the unit. The unit facilitates product marketing in a broader market through their outlets. The unit is also providing assistance in regard to packaging standard, branding, product development and quality control of the product.

In addition to identifying certain elements in university research activity and technology transfer activity at both universities, I have also observed that several problems occurred at both universities with regards to technology transfer activities. Such problems included limited research facilities, limited research financial support, technology transfer management system, strategy for utilization, including manufacturing and marketing, incentives for researchers, university and industry relations, suitable schemes for U-I (university-industry) relation, government support for technology transfer activity, trust in U-I relations, identification of counterparts for utilization and commercialization, and so on. Although supported by limited resources and despite encountering several problems as described above, both universities have been able to conduct some technology transfer activities. However, records of technology transfer activities are is still limited.

\section{CONCLUSION}

Based on the empirical study conducted at 2 (two) universities, namely IPB and UI, activities related to university technology transfer have indeed involved IPR protection for technology and product resulting from research activity at the said universities. Specifically in the technology development phase, most of the research results are expected to obtain IPR protection. Universities are encouraging researchers to protect research results mostly under the patent regime, and some research results under copyrights. At both universities, patenting activities have increased over the last 10 (ten) years. To some extent, intellectual property protection has been considered as an important aspect by universities for academic record purposes and as an indicator of the achievements of the university as well as of its researchers. For patents, in particular, inventors will receive a number of credit points which is useful for their academic career and promotion, as an incentive.

However, in terms of technology transfer activities (technology utilization phase), IPRs do not seem to be playing a significant role. Ownership of IPRs in a product or technology does not significantly boost the transfer of technology from the university side to the industry side. IPRs are not yet perceived as a good incentive for either the university or the industry, particularly in terms of the financial aspect. In fact, record of patenting activity has been increasing over the last 10 years; however, unfortunately, the records of university and industry collaboration are still limited.

In addition, the IPB holding company (BLST.Co.), which is closely involved in technology transfer activities, also stated that with or without IPRs, technology utilization still occurs. To facilitate university technology transfer, BLST Co. does not require a patent or other IP protection for technology utilization. Once the product 
is patented, it will be of added value; however, if it is not patented, it would pose no problem for them in conducting product utilization.

At UI, patent licensing did occur, however only for a few products. The university IP office is still making endeavors to find counterparts for the university's products or technology. At UI, technology transfer has also been conducted through community service program. Through the community service program, research output is disseminated for public benefit. Under such program, the ownership of patent or other IPRs is perhaps not necessary. Technology transfer has also been conducted through a voluntary system for social purposes by Prof. Raldi. Under such voluntary system, patent has not been a relevant issue.

In the context of Indonesian state universities, ownership of a patent as an incentive ${ }^{71}$ only brings an impact to a certain extent. It is mainly related to academic record purposes as an achievement of the university and its researchers. Patent as an incentive in technology transfer, in the form of financial benefit to the owner of the product or technology and incentive to the industry, has had certain impact albeit limited. The next challenge is how to boost an active transfer of technology from university to industry while creating academic benefit, public benefit and financial benefit at the same time.

\section{Acknowledgements}

This paper is part of ongoing doctoral research. The author would like to thank Associate Professor Ryu KOJIMA and Professor Shinto TERAMOTO at Kyushu University as the supervisor of this research. I would also like to thank all respondents from Institut Pertanian Bogor (IPB) and Universitas Indonesia (UI) who contributed their time in sharing their experiences on this issue, special thanks to Ms. Anggia Murni, Mr. Dwiko Gunawan, Ms. Dyah Iswantini, Mr. Edy Djauhari Purwakusumah, Ms. Effionora, Mr. Engkus Kuswara, Mr. Hendra Wibowo, Mr. Heri Ahmad Sukria, Ms. Lenny Mykel Muliawati, Mr. Meika Syahbana Rusli, Mr. Muhamad Sahlan, Mr. Raldi Artono Koestoer, and Ms. Wanti Wulandari.

${ }^{71}$ Lemley, "Are Universities Patent Troll?". 


\section{Bibliography}

\section{Legal documents}

United States of America, 35 U.S. Code Chapter $18 \S 200-212$ - Patent Rights in Inventions Made with Federal Assistance.

\section{Books}

Alikhan, Shahid, Socio-Economic Benefit of Intellectual Property Protection In Developing Countries. Geneva: WIPO, 2000.

Bainbridge, David and Claire Howell, Intellectual Property Asset Management: How To Identify, Protect, Manage and Exploit Intellectual Property Within the Business Environment, $1^{\text {st }}$ Edition, 2014.

World Intellectual Property Organization and International Trade Center. Exchanging Value Negotiating Technology Licensing Agreement-A Training Manual. Geneva: WIPO and ITC, 2005.

Cooter, Robert and Thomas Ulen. Law \& Economics. 6th Ed. Boston: Addison-Wesley, 2008.

Das, Satya P. Microeconomics for Business. Thousand Oaks, CA: SAGE Publications, 2007.

Garner, Bryan A. Black's Law Dictionary. $7^{\text {th }}$ ed. St. Paul, Minnesota: West Publishing, 1999.

Universitas Indonesia, Direktorat Riset dan Pengabdian Masyarakat. Laporan 5 tahun DRPM UI 2008-2012 [5 Year Report of the Directorate of Research and Community Engagement Universitas Indonesia 2008-2012]. Depok: Universitas Indonesia, 2012.

$\mathrm{Ku}$, Katharine. "Is Technology Transfer a Winning Proposition?." In Developing University-Industry Relations - Pathways to Innovation from the West Coast. Eds. Robert C. Miller, Bernard J. Le Boeuf and Associates, 17-30. British Columbia: Wiley, 2009.

Manurung, Amir F., Komersialisasi Teknologi, [Commercialization of Technology], 2012.

Manurung, Amir F. Komersialisasi Teknologi [Technology Commercialization]. Jakarta: Kementerian Riset dan Teknologi, 2012.

Miller, Robert C. and Bernard J. Le Boeuf. "Context and Constraints." In Developing University-Industry Relations - Pathways to Innovation from the West Coast. Eds. Robert C. Miller, Bernard J. Le Boeuf and Associates, 1-6. British Columbia: Wiley, 2009.

Miller, Robert C. "University - Industry Research Agreement." In Developing UniversityIndustry Relations - Pathways to Innovation from the West Coast. Eds. Robert C. Miller, Bernard J. Le Boeuf and Associates, 7-16. British Columbia: Wiley, 2009.

Nezu, Risaburo, et. al.. Technology Transfer, Intellectual Property And Effective University-Industry Partnership The Experience of China, India, Japan, Philippines, The Republic Of Korea, Singapore and Thailand. Geneva: WIPO, 2007.

Ogus, Anthony I. Regulation: Legal Form and Economic Theory. Oxford: Clarendon Press, 1994.

Smith, Adam and J. Shield Nicholson, An Inquiry Into the Nature and Causes of Wealth of Nation or Wealth of Nations. London: W. Strahan and T. Cadell, 1887.

Widjaja, Gunawan. Lisensi [Licensing]. 1st ed. Jakarta: Rajawali Pers, 2001. 


\section{Articles}

Boseman, Barry. "Technology Transfer and Public Policy: A Review of Research and Theory," 29 Research Policy 29 (2000): 627-655.

Casey, Anthony J. and Andres Sawicki. "Copyright in Teams." University Of Chicago Law Review 80 (2013): 1683-1741.

Coase, Ronald. “The New Institutional Economics." The American Economic Review 88, no. 2 (1998): 72-74.

Elfahmi, Herman J. Woerdenbag, and Oliver Kayser, "Jamu: Indonesian Traditional Herbal Medicine towards Rational Phytopharmacological Use." Journal of Herbal Medicine 4 (2014): 51-73.

Hamel, Gary. "Bringing Silicon Valley Inside." Harvard Business Review (1999): 70-84.

Lemley, Mark A. "Are Universities Patent Troll?," Fordham Intellectual Property, Media And Entertainment Law Journal 18 (2008): 611-631.

Lockett, Andy, Mike Wright and Stephen Franklin. "Technology Transfer and Universities' Spin-Out Strategies." Small Business Economics 20 (2003): 185-200.

McDevitt, Valerie Landrio., Joelle Mendez-Hinds, David Winwood, Vinit Nijhawan, Todd Sherer, John F. Ritter and Paul R. Sanberg. "More Than Money: The Exponential Impact of Academic Technology Transfer." Technology And Innovation 16 (2014): 75-84.

Mowery, David., Richard Nelson, Bhaven Sampat,and Arvids Ziedonis. "The Growth of Patenting and Licensing by U.S. Universities: An Assessment of the Effects of the Bayh-Dole Act of 1980." Research Policy 30 (2001): 99-119

Powers, Joshua B. and Patricia P. McDougall. "University start-up formation and technology licensing with firms that go public: a resource-based view of academic entrepreneurship." Journal of Business Venturing 20 (2005): 291-311.

Rasmussen, Einar, Øystein Moen, and Magnus Gulbrandsen. "Initiatives to Promote Commercialization of University Knowledge." Technovation 26 (2006): 518-533.

Smilor, Raymond W., David V. Gibson, and Glenn B. Dietrich. "University Spin-Out Companies: Technology Start-Ups From UT-Austin." Journal Of Business Venturing 5 (1990): 63.

Telser, Lester, Willian Best, John W. Egan, Higinbotham N. Harlow, "The Theory of Supply with Applications to The Ethical Pharmaceutical Industry." Journal of Law And Economics 19 (1975): 449 -478.

Toshiko, Takenaka. "Technology Licensing and University Research in Japan." International Journal of Intellectual Property Law, Economic and Management 1 (2005): 27-36.

Wakoh, Steven Collins and Hikoji. " Universities and Technology Transfer in Japan: Recent Reforms in Historical Perspective." Journal Of Technology Transfer 25 (2000): 213-22.

West, Darrell M. "Improving University Technology Transfer and Commercialization." 20 Technology Innovation 20 (2012): 1-15.

Nasution, Reza., Dadan Djuanda, Rifa Rachmah. "Studi Literatur tentang Komersialisasi Teknologi di Perguruan Tinggi: Proses, Potensi, Model dan Aktor [Literature Study on the Commercialization of Technology at Universities: Process, Potentials, and Actors]." Jurnal Manajemen Teknologi 8, no. 2 (2008) 


\section{Websites}

Adawiah, Tri Aji Purno and Yoga Edi Ragil. "Komersialisasi Teknologi dalam Upaya Peningkatan Daya Saing Industri Indonesia [Technology Commercialization in the Effort on Improving Indonesia Industrial Competitiveness]." $\quad$ Https://Www.Academia.Edu/6780195/ Komersialisasi Teknologi Dalam Upaya Peningkatan Daya Saing Industri_Indonesia. Accessed 15 March 2016.

Angrist, Joshua and Alan B. Krueger. "Instrumental Variables and the Search for Identification: From Supply and Demand to Natural Experiments." Working paper 8456 http://www.nber.org/papers/w8456. Accessed 15 March 2016.

Antangin. "Penelitian." http://www.antangin.com/penelitian.php.

Association of University Technology Managers. "The Bayh Dole Act: It's Working." http://www.autm.net/AM/Template.cfm?Section=Bayh Dole Act $\&$ Template $=/ \mathrm{CM} /$ ContentDisplay.cfm\&ContentID=11603. Accessed 15 March 2016.

Association of University Technology Managers. "The Bayh Dole Act." http://www. autm.net/Bayh Dole Act1.htm. Accessed 15 March 2016.

Associations of University Intellectual Property and Technology Management, "Members." http://unitt.jp/en/member. Accessed 15 March 2016.

Badan Pengkajian dan Penerapan Teknologi (Agency for the assessment and aplication of tecnology). "Pengembangan Teknologi produksi obat bahan alam bppt menarik minat peneliti asing." http://www.bppt.go.id/index. php/teknologi-agroindustri-dan-bioteknologi/350-pengembanganteknologi-produksi-obat-bahan-alam-bppt-menarik-minat-penelitiasing. Accessed 15 March 2016.

Bloomberg Business. "Company Overview of PT. Bintang Toedjoe." http:// www.bloomberg.com/research/stocks/private/snapshot. asp?privcapId=31065421.

Business dictionary. "Blanket Authorization" http://www.businessdictionary.com/ definition/blanket-authorization.html

California State University. "Price Theory - Supply and Demand." http://www.csun. edu/ dgw61315/PTlect2y.pdf. Accessed 15 March 2016.

Central Intelligence Agency. "The World FactBook." https://www.cia.gov/library/ publications/the-world-factbook/geos/id.html

Chou, S. K.. "Development Of University - Industry Partnerships For The Promotion Of Innovation And Transfer Of Technology: Singapore." http://www.wipo. int/export/sites/www/uipc/en/partnership/pdf/ui partnership sg.pdf. Accessed 15 March 2016.

Direktorat Riset dan Pengabdian Masyarakat UI. "Penyelenggaraan Kegiatan Riset tahun 2013." http://research.ui.ac.id/main/research/research. Accessed 15 March 2016.

Fisher,Lawrence. "TheInnovation Incubator: TechnologyTransferatStanfordUniversity." http://www.strategy-business.com/article/13494?gko=e8e48. Accessed 15 March 2016.

Henderson, Jennifer and John Smith. "Academia, Industry, and the Bayh-Dole Act: An Implied Duty to Commercialize." https://www.cimit.org/news/ regulatory/coi part3.pdf.

Indonesia, Ministry of Health of the Republic of. "Grafik Rekapitulasi IOT, [Recapitulaion Diagram of IOT]." http://binfar.kemkes.go.id/2013/02/ 
grafik-rekapitulasi-iot/. Accessed 15 March 2016.

Indonesia, Ministry of Industrial Republic of. "Direktori Perusahaan Industri, [Directory of Industrial Companies]." http://www.kemenperin.go.id/ direktori-perusahaan?what=herbal\&prov=0\&hal=1. Accessed $15 \mathrm{March}$ 2016.

Jamu Jago. "Company Profile." http://www.jago.co.id/index.php?option=com_conten t\&view=article\&id=6\&Itemid=55. Accessed 15 March 2016.

Lembaga Penelitian dan Pengabdian kepada Masyarakat IPB. "Data Hasil PPM Kompetitif yang di Koordinasi LPPM IPB Berdasarkan Sumber Dana (Data dari tahun 2013 sampai 2014)." http://web.ipb.ac.id/ lppm/ lppmipb/statistik/sumberdana.php. Accessed 15 March 2016.

Marwati. "Development of Herbal Medicines in Indonesia Still Open." http://ugm. ac.id/en/news/5557-development.of.herbal.medicines.in.indonesia. still.open. Accessed 15 March 2016.

Murai, Shunji.. "Technology Transfer for Suistanable Development in Developing Countries, International Archives of Photogrammetry and Remote Sensing." Vol XXXIII, Part B6. Amsterdam 2000, Page 351, http://www. isprs.org/proceedings/XXXIII/congress/part6/351 XXXIII-part6.pdf. Accessed 15 March 2016.

Nishio, Koji. "Development of University-Industry Partnerships for the Promotion of Innovation and Transfer of Technology: Japan." Http://Citeseerx.Ist. Psu.Edu/Viewdoc/Download;Isessionid=7ea49a844863ff02ced17af b2c7ee78b?Doi=10.1.1.129.1837\&Rep=Rep1\&Type=Pdf. Accessed 15 March 2016.

Nithad, Krisnachinda. “Thailand's Experience in Fostering University-Industry Partnerships." available at Accessed 15 March 2016. http://www.wipo. int/export/sites/www/uipc/en/partnership/pdf/ui partnership th.pdf.

Ono, Suparno., Hermawan Aji and Syuaib Faiz. "Technopreneurship." http://ono. suparno.staff.ipb.ac.id/articles/technopreneurship-2/.

Republic of Indonesia, Ministry of Research and Technology. "Diskusi PP 20/2005 tentang Alih Teknologi dan Pemanfaatan Hasil Litbang Bersama LPPM Jabodetabek." [Discussion on Government Regulation 20/2005 concerning Transfer of Technology and Joint Utilization of Research Center's Results with LPPM Jabodetabek], http://www.ristek.go.id/ index.php/module/News+News/id/13379. Accessed 15 March 2016.

Rubin, Paul H.. "Law and Economics." http://www.econlib.org/library/Enc/ LawandEconomics.html. Accessed 15 March 2016.

Russell, Brandom. “Google's 'perfect human' project isn't evil, it's business -Baseline's research could make a huge splash in the fight over health data." http:// www.theverge.com/2014/7/28/5943999/googles-perfect-humanproject-isnt-evil-its-business. Accessed 15 March 2016.

Setiadharma, Prayudi. "Bank Paten dan Upaya Melawan Patent Troll." [Patent Bank and Endeavors for Combating Patent Trolls], http://psetiadharma. wordpress.com/2011/10/14/bank-paten-dan-upaya-melawan-patenttroll/. Accessed 15 March 2016.

Srinivas, Hari. "Technology Transfer for Sustainable Development." http://www.gdrc. org/techtran/techtran-sustdev.html. Accessed 15 March 2016.

Suyitno, Ade and Nurul Aisyah. "Developing Nusantara Green Pharmacy Village (Ngpvill) Trough Herbal Entrepreneurship Program In Indonesia, Paper prepared for AISC Taichung Taiwan, Asia University 27-29 April 2013." 
http://islamic-entrepreneurship.blogspot.jp/2013/08/developingnusantara-green-pharmacy.html. Accessed 15 March 2016.

Teramoto, Shinto and Paulius Jurcys. "Intermediaries, Trust and Efficiency of Communication: A Social Network Perspective." http://ssrn.com/ abstract $=2270254$. Accessed 15 March 2016.

Tilaar, Martha.. "History." http://www.marthatilaar.com/company_history.html. Accessed 15 March 2016.

Triple Helix Research Group Stanford University. "The Triple Helix Concept.” http:// triplehelix.stanford.edu/3helix_concept. Accessed 15 March 2016.

Whelan, Joseph and Kamil Msefer. "Economic Supply \& Demand." http://ocw.mit. edu/courses/sloan-school-of-management/15-988-system-dynamicsself-study-fall-1998-spring-1999/readings/economics.pdf. Accessed 15 March 2016.

World Health Organization Regional Office for South East Asia. "Traditional Medicine in Republic of Indonesia." http://www.searo.who.int/entity/medicines/ topics/traditional medicines in_republic of indonesia.pdf. Accessed 15 March 2016.

Yi, Hwa-Cho. "Korean Experience In Fostering University-Industry Partnerships." http://www.wipo.int/export/sites/www/uipc/en/partnership/pdf/ ui partnership kr.pdf. Accessed 15 March 2016.

\section{Interviews}

Effionora, Interview with Prof. Effionora, Researcher, Inventor and Dean of Pharmacy Faculty Universitas Indonesia, At Dean's Office of Pharmacy Faculty Universias Indonesia, Depok, Indonesia (May 12, 2015).

Gunawan, Dwiko., Interview with Mr. Dwiko Gunawan, General Manager of SERAMBI BOTANI, Subsidiary of BLST Co. - Holding Company of Institut Pertanian BogorInstitut Pertanian Bogor, at Serambi Botani Office, Taman Kencana, Bogor, Indonesia (May 20, 2015).

Iswantini, Dyah., Interview with Prof. Dr. Dra. Dyah Iswantini, M.Sc.Agr., Lecturer of Chemical Department Faculty of Mathematics and Science, Researcher and Inventor of Herbal Pharmacy Product, Institut Pertanian BogorInstitut Pertanian Bogor, at Directorate Research and Innovation, Dramaga Campus, Institut Pertanian BogorInstitut Pertanian Bogor, Bogor, Indonesia (May 21, 2015).

Koestoer, Raldi Artono., Interview with Prof. Dr. Ir. Raldi Artono Koestoer DEA., Researcher, Inventor and Lecture of Engineering Faculty Universitas Indonesia, In Engineering Faculty Universitas Indonesia, Depok, Indonesia (May 19, 2015).

Kuswara, Engkus., Interview with Mr. Engkus Kuswara, Officer at Sub Directorate of IP Development and Management/ IP Office University - Directorate of Innovation and Business Incubator Universitas Indonesia, through email (respondent in Depok, Indonesia), (September 12, 2015).

Kuswara, Engkus, Interview with Mr. Engkus Kuswara, Officer at Sub Directorate of IP Development and Management / IP Office University- Directorate of Innovation and Incubator Business Universitas Indonesia, In Science Park Building Universitas Indonesia, Depok, Indonesia (May 8, 2015).

Muliawati, Lenny Mykel., Interview with Ms. Lenny Mykel Muliawati, Officer at Sub Directorate Community Service and Research Commercialization - 
Directorate of Research and Community Service Universitas Indonesia, In Integrated Research Laboratory Center Building Universitas Indonesia, Depok, Indonesia (May 11, 2015).

Murni, Anggia., Interview with Ms. Anggia Murni S.Si, Officer at Collaboration and Networking Division of BioPharmaca Research Center, Institut Pertanian Bogor, In BioPharmaca Research Center, Taman Kencana, Bogor, Indonesia (May 20, 2015).

Purwakusumah, Edy Djauhari., Interview with Drs. Edy Djauhari Purwakusumah, MSi., Executive Secretary and Head of Division of Natural Resources Development and Cultivation BioPharmaca Research Center, Lecture in Bio Chemical Department, President Director of PT. Biofarindo (SpinOff Company), In Bio Chemical Department, Dramaga Campus, Insitut Pertanian BogorInstitut Pertanian Bogor, Bogor, Indonesia (May 21, 2015).

Rusli, Meika Syahbana., Interview with Dr Meika Syahbana Rusli, President Director of PT Bogor Life Science and Technology - Holding Company of Bogor Agricultural University, In PT Bogor Life Science and Technology, Taman Kencana, Bogor, Indonesia (May 20, 2015).

Sahlan, Muhamad., Interview with Dr. Eng. Muhamad Sahlan, S.Si. M.Eng, Researcher, Inventor and Lecture of Engineering Faculty Universitas Indonesia, In Lecture Room of Chemical Engineering Department, Faculty of Engineering Universitas Indonesia, Depok, Indonesia (May 13, 2015).

Sukria, Heri Ahmad., Interview with Dr. Ir. Heri Ahmad Sukria, M.Sc.Agr, Deputy Director for Business Control, Directorate of Business Development, Institut Pertanian Bogor, In Directorate of Business Development, Dramaga Campus, Institut Pertanian Bogor, Bogor, Indonesia (May 26, 2015).

Teramoto, Shinto., Discussion with Professor Shinto Teramoto, Professor at Kyushu University, In Fukuoka, Japan (March 31, 2015).

Wibowo, Hendra., Interview with Mr. Hendra Wibowo, Officer at Directorate Research and Innovation, Institut Pertanian Bogor, In Directorate Research and Innovation Office, Dramaga Campus, Bogor, Indonesia (May 21, 2015).

Wulandari, Wanti., Interview with Ms. Wanti Wulandari, Officer at Sub Directorate Research Planning and Development - Directorate of Research and Community Service Universitas Indonesia, In Integrated Research Laboratory Center Building Universitas Indonesia, Depok, Indonesia (May 11, 2015).

\section{Others}

Romadoni, Ahdiar., Patent Valuation Strategy (September 27-28, 2013) (Unpublished presentation, Institut Teknologi Bandung) (on file with the author). 